sunably a surface collection. It is therefore possible that more than one industry is present. The assemblago has boen studied in detail and more than a hundred artefacts are illustrated. It is evident that the importance of adequate reportage of such sites has been realized. It is, however, unfortunate that the illustrations are often not sufficiently well reproduced to allow a check to be made on the author's claims. The artefacts have been classified as flake-blades, blades, flakes, coros and finished tools. It is with the tools that the classification is not so fortunate. Often the claimed retouch may be no more than casual batter, or at the best utilization, and utilized or retouched artefacts are sometimes identified as scrapers or other finished tools. A flake (Fig. 9.1.) possibly, but not certainly, retouchod is, for oxamplo, classified as a thumb-nail scraper. There are, indeed, some good examples of blades and blade cores similar to those illustrated from tho Indus Valloy sitos, but none of the so-called burins is convincing. The author concludes that there may be three industries present, but there is little evidence to justify this conclusion and still less to draw parallels with the European industrial succession.

\section{Forestry Research in East Africa}

A sUMMARY of forestry research work being carriod out in East Africa is given in the 1961 report of the East African Agriculture and Forestry Research Organization, Kikuyu, Kenya (Pp. vii + 104. Kikuyu, Kenya: Fast African Agriculture and Forestry Research Organization, 1962). Catchment area research forms one of the important series of long-term investigations. It has been shown that both tall montane rain forest and bamboo forest are efficient regulators of storm-flow, giving only some 1.5 per cent run-off of the annual rainfall, whereas overgrazed semi-arid catchments resulted in 40 por cont of the annual rainfall being lost as surface run-off. Interesting observations have been made of the root systems of the vascular plants in catchmont aroas. In one caso, roots have been excavated to a depth of $25 \mathrm{ft}$. with a lateral root range exceeding $35 \mathrm{ft}$., penetrating highly metamorphosed schistose and gneissic basoment complex strata. Preliminary surveys show that a wide range of plants can intercept and store light rainfall in useful amounts. This accumulation of water in the soil near the base of the tree Balanites aegyptiaca (well known in much of the savannah-woodland of Africa) may play an impor. tant part in thicket formation.

\section{The Selby Fellowship}

THE Selby fellowship has been established by the Australian Academy of Science to bring graduates of promise and proved capacity for research to work in the laboratories of universities or research institutions in Australia. The followship may be awardod in any branch of physical or biological science, and is tenable at any university or research institution in Australia, normally for one full year of work. Candidates must have taken their first degree and have had preliminary rosearch experience at some university in a country other than Australia. Each applicant should (unless some special considerations are advanced) be less than thirty years of age on July 1 in the year in which the application is received. Applicants should in general hold a Ph.D. degree or have equivalent status and experience, but the followship will not normally be given to those who have already held a senior research award. The Selby fellowship carries a stipend of $£ 2,000$ (Australian) per annurn. The costs of tho Follow's travol to Australia and back to his country of origin at the conclusion of the fellowship will be provided, up to a limit of $£ A 500$, including dependants, if any. Whoro it is essontial for the prosecution of the work carried out during the tenure of the fellowship, a limited sum may be allocated for travol within Australia. Each applicant is roquirod to state the gonoral nature and scope of the reseurch that he wishes to undertake, and the university departmont or research institution in which he seeks to work. Applications should bo sent by July 30 to the Assistant Secretary, Gordon Street, Canberra City, A.C.T., from whom further information can be obtained.

\section{University News:}

Birmingham

Tre following appointments have been announced: Lecturer, Dr. A. J. Edwards (chemistry); Dr. K. R. Gray (chemical engineering); Dr. R. Schurrman (chemical engineering); Mr. E. A. Staton (chemical ongineering). Research Fellow, Dr. K. W. Buck (chemistry); Mr. D. J. Creasey (G. E. C. Hirst Research Fellow in the Department of Electrical Engineering); Mr. I. L. Dillamoro (industrial metallurgy); Dr. R. J. Heitzmann (anatomy); Mr. B. C. Lam (eleotrical engineering); Mr. L. A. Adorjan (mining and minerals engineering).

Leeds

THE following appointments have been announced: Lecturer, Dr. L. R. A. Bradshaw (oxperimental pathology and cancer research); Dr. J. P. Cleave (pure mathematics); Mr. J. R. Flower (chemical engineering). Research Fellow, Dr. J. G. Blumler, as Granada T.V. Research Fellow in the Department of Social Studies.

Nottingham

DR. G. Power, senior lecturer in tho Department of Mathematics, has been appointed to a readership in applied mathematics. Dr. A. J. M. Spencer, lecturer in the Department of Theoretical Mochanies, has been appointed to a readership in the same Department.

Southampton

DR. J. WRIGLEY has been appointed to the second chair of education with effect from September 1. The following appointments to lectureships have been announced: Dr. M. Akhtar (physiology and biochomistry); Mr. J. E. G. Barnett (physiology and biochemistry); Dr. A. K. Huggins (physiology and biochemistry); Dr. R. J. Walker (physiology and biochemistry). Promotions to senior lectureships are as follows: Mr. J. R. Armstrong (adult education); Mr. D. J. Mead (aeronautics and astronautics); Dr. H. M. Frey (chomistry); Dr. J. R. Rydzewski (civil engineering); Mr. B. H. Venning (electronics).

\section{Announcements}

Prof. C. H. Graram, of Columbia University, has been awarded the Edgar D. Tillyor Modal for 1963 of the Optical Society of America for his contributions to visual science.

THE fifteenth international symposium of phytopharmacy and phytiatry, arranged under the auspices of tho Ministry of National Education and Culture and the Ministry of Agriculture, will be held at the Agricultural Institute, Ghent, on May 7. Further information can be obtained from Rijkslandbouwhogeschool, Coupure links 235, Ghent.

A sUMMrer school in theoretical physics, arranged by the Ministry of Scientific Research and Cultural Affairs, Government of India, will bo hold at Kodaikanal during June 1-15. The field of study at the summer school will bo rocont devolopments in high-enorgy physics. Further information can be obtained from the Director, Mat. seience, Madras 4, India.

Trif National Physical Laboratory is holding open days during May 15-16. Exhibits of work in progress will be on display, and the following lectures will be given: tho work of the Aerodynamies Division (Dr. W. P. Jones); experiments with ship models (A. Silverleaf). Further information can be obtained from the National Physical Laboratory, Teddington, Middlesex. 